of which the late Prof. E. Percival had long been an enthusiastic protagonist still flourishes. Hence, MacIntyre's acknowledgements will please Prof. Percival's former pupils and friends in Britain as well as in Now Zealand.

\section{Quaternary Industries in Poland}

The site of the Quaternary industries at Racibórz.Ocice, Poland, is well known but has only recently been properly investigated. An article in Folia Quaternaria (1963), published by the University of Cracow, is well worth the attention of students interested in the Polish Middle Stone Age. At the site there are three main layers of loess resting on a gravel terrace. Between the lowest of these and the top of the gravel a thin layer of soil containing remains of pine can be detected. This layer, however, does not occur farther north. Various accumulations of loess, which form the three main series, follow, and it is at the base of the lowest layer that chipped tools first appear and continue throughout the upper ones. These industries, so far as can be judged from the illustrations, all belong to the Middle Stone Age and the levallois technique can be noted. However, a little Upper Palæolithic is claimed from the later levels. The top of the gravel and the earliest loess would seem to date to the decline of the main Würmian glaciation. The article, which is written in French, is well produced and illustrated; sections are also given.

\section{The Night Sky in April}

New moon occurs on April 12d 12h $38 \mathrm{~m}$ U.T. and full moon on April $26 \mathrm{~d} 17 \mathrm{~h} 50 \mathrm{~m}$. The following conjunctions with the Moon occur: April 8d 20h, Saturn $3^{\circ}$ N.; April $15 \mathrm{~d} 18 \mathrm{~h}$, Venus $6^{\circ} \mathrm{N}$. Venus is in conjunction with Aldebaran on April $14 \mathrm{~d} 22 \mathrm{~h}$, Venus being $9^{\circ} \mathrm{N}$. Mereury is an evening star, visible low in the west after sunset; it sets about two hours after the Sun on April 9, and is favourably situated for observation during the first three weoks of the month. Venus is an evening star, favourably situated for observation, setting at $23 \mathrm{~h} 10 \mathrm{~m} .23 \mathrm{~h} 35 \mathrm{~m}$ and $23 \mathrm{~h} 50 \mathrm{~m}$ on April 1,15 and 30 , respectively. Its stellar magnitudo is $-4 \cdot 0$; its distance decreases during the month from 73 to 51 million miles, and the visible portion of the apparent disk from 0.559 to 0.378 . Mars, Jupiter and Saturn are too close to the Sun for observation. There is one occultation of a star brighter than magnitude 6 visible at Greenwich: $\vee$ Sco. $m$. disappearance April 28d 23h 54.2m, reappearance April 29d 01h 09.6m. The Lyrid meteors are active during April 19-22, but conditions for observation are unfavourable.

\section{University News :}

Belfast

DR. A. R. BoothroYd, reader in electronics at the Imperiel College of Science and Technology, has been appointed to the chair of electronics. Dr. M. Rudge has been appointed to a lectureship in applied mathematics.

\section{Cambridge}

THe following elections into fellowship at Churchill College, Cambridge, have been announced: Title $A$, Dr. J. H. Brunton, of Gonville and Caius College and University lecturer-elect in engineering; L. M. Harvey, of St. Catharine's College and deputy secretary genoral of the Eaculties. Title B, T. Lewis, for research in management studies during July-September 1964 (Allen Clark senior research fellowship); Dr. R. R. Farquharson, for research in management studies from Ootober 1, 1964 (Allen Clark senior research fellowship). Title $F$ (Overseas Fellowship), Prof. J. J. Michalski, of Christ's College and professor of organio chemistry at Łodz Technical University.

London

Prof. M. W. Thring, professor of fuel technology and chemical engineering in the University of Sheffield, has been appointed to the chair of mechanical engineering tenable at Queen Mary College. Dr. K. R. Dumbell, senior lecturer in bacteriology in the University of Liver. pool, has been appointed to the Fleming chair of virology tenable at St. Mary's Hospital Medical School. Dr. D. R. Hughes, associate professor in the University of Michigan, has been appointed to the readership in mathematies tenable at Westfield College. Dr. W. B. Robertson, senior lecturer in morbid anatomy in the University of the West Indies, has been appointed to the readership in morbid anatomy tenable at St. George's Hospital Medical School. The following titles have been conferred: professor of mathematies, on Dr. J. Taylor, in respect of his post at Westfield College; reader in crystallography, on Dr. J. W. Jeffery, in respect of his post at Birkbeck College; reader in geophysies, on Dr. R. G. Mason, in respect of his post at the Imperial College of Science and Technology.

St. Andrews

The following appointments to lectureships have been announced: St. Salvator's College, Dr. B. C. Challis (chemistry); Queen's College, J. J. McMullen (physics), and Dr. A. W. Murray (chemistry).

\section{Announcements}

A sxmposiom in memory of the late Prof. E. J. King, arranged by the Association of Clinical Biochemists, will be held at the Postgraduate Medical School, London, on April 18. The speakers will be former colloagues of Prof. King, and their papers will review and report recent advances in several fields of clinical biochemistry. Further information ean be obtained from Dr. D. W. Moss, Postgraduate Medical School, Ducane Road, London, W.12.

A course on "Comparative Physiology and Pathology of the Skin", arranged by the School of Clinical Research and Postgraduate Medical Teaching and the School of Veterinary Medicine of the University of Cambridge, will be held in Cambridge during April 6-11. Subjects to be considered will include: comparative dermatology; hair; nutritional influences on the skin; porphyria and light sensitization; the mast cell; immunology; tumours of the skin. Further information can be obtained from the Secretary, University Medical School, Tennis Court Road, Cambridge.

A conference on "The Use of Electron Microscopy, Diffraction and Probe Analysis in the Identification of Precipitates in Solids", arranged by the Electron Microscopy and Analysis Group of the Institute of Physies and the Physical Society, will be held at the National Physical Laboratory, Teddington, during April 16-17. The programme will be devoted to the identification of crystal structure and analysis of precipitates in thin films and extraction replicas. Further information can be obtained from the Administration Assistant, Institute of Physies and the Physical Society, 47 Belgrave Square, London, S.W.1.

THE annual conference of the Ergonomics Research Society on "The Psychological and Physiological Assessment of Work Capacity and Work Load" will be held at the Welsh College of Advanced Technology, Cardiff, during April 6-9. Topics under discussion will include: job redesign for the older worker; the concepts of capacity and load in relation to work; assessing mental load in process operators; visual fatigue; measuring fatigue over a twelve-hour spell of driving; effects of monotony on psychophysical functions; the measurement of energy expenditure; psychological and physiological assessment of working capacity. Further information can be obtained from J. Spencer, Department of Psychology, 8-10 Berkoley Square, Bristol 8. 